\title{
Effect of Calcium Metalosate on Growth and Yield of Tomato (Lycopersicon esculentum Mill.)
}

\author{
R. Jayaramaiah ${ }^{1 *}$, A. Nataraja ${ }^{1}$, B.T. Naveen Kumar ${ }^{2}$ and G. Pramod $^{2}$ \\ ${ }^{1}$ Department of Agronomy, ${ }^{2}$ Department of Horticulture, College of Agriculture, Hassan, \\ Karnataka, India \\ *Corresponding author
}

\section{A B S T R A C T}

\begin{tabular}{|l|}
\hline Key w or d s \\
Calcium Metalosate, \\
Growth, Total dry \\
matter production, \\
Fruit and Yield \\
\hline Article Info \\
\hline $\begin{array}{l}\text { Accepted: } \\
\text { 12 September } 2018 \\
\text { Available Online: } \\
\text { 10 October } 2018\end{array}$ \\
\hline
\end{tabular}

Field trail was carried out at the farm unit, College of Agriculture, Hassan Karnataka during the year 2015 to study the effect of foliar application of calcium metalosate on growth and yield of tomato. The experiment consisted of 7 treatments viz., $\mathrm{T}_{1}$ : Control, $\mathrm{T}_{2}$ : Calcium metalosate @ $1 \mathrm{ml} / \mathrm{l}, \mathrm{T}_{3}$ : Calcium metalosate @ $2 \mathrm{ml} / \mathrm{l}, \mathrm{T}_{4}$ : Calcium metalosate @ $3 \mathrm{ml} / \mathrm{l}, \mathrm{T}_{5}$ : Calcium metalosate @ $4 \mathrm{ml} / \mathrm{l}, \mathrm{T}_{6}$ : Micnef @ $5 \mathrm{~g} / \mathrm{l}$ and $\mathrm{T}_{7}$ : Samras (amino acid mixture) @ $2 \mathrm{ml}$. The experiment was laid out in randomized complete block design and replicated thrice. Application of calcium metalosate at different concentration had significant influence on productivity of tomato. At harvest, application of calcium metalosate@ $4 \mathrm{ml} / \mathrm{l}\left(\mathrm{T}_{5}\right)$ recorded significantly higher plant height $(126.08 \mathrm{~cm})$, more number of leaves (52.80), number of branches per plant (16.10), total dry matter production (152.13 $\mathrm{g} \mathrm{plant}^{-1}$ ), numbers of fruit per plant (32.15), Average weight of ten fruits (998.00 grams), keeping quality of fruits (33.66 mean value in days) and total yield (25.22 $\left.\mathrm{t} \mathrm{ha}^{-1}\right)$ as compared to control $\left(\mathrm{T}_{1}\right)$ which was on par with calcium metalosate @ 3 $\mathrm{ml} / \mathrm{l}\left(\mathrm{T}_{4}\right)$.

\section{Introduction}

Tomato (Lycopersicon esculantum Mill.) is one of the most important popular and extensively used vegetable crops of solanaceae family.

The fruits are consumed as raw or cooked, processed i.e. to produce soup, juice, ketchup, puree, paste, and even powder. It is a rich source of Vitamin $\mathrm{C}$ and adds variety of colour and flavour to the food. Green tomatoes are also used for pickles and preserves.
Exploitation of maximum production potential (fruit yield) of crop is limited by any one of the several factors like irrigation, fertilizer and plant protection measures. For intensive cultivation aiming at higher production by balanced fertilization with major and minor nutrient elements with optimum doses becomes imperative. It is generally believed that micronutrients are present in adequate quantities in Indian soils, with this assumption, in the past the growers were generally advised to apply required doses of NPK for higher crop yields. It is, however, 
now realized that high doses of NPK alone are not sufficient to increase the production of vegetables and thus the need for micronutrients management has been felt.

Due to non-availability and high cost of farm yard manure, the vegetable growers of different regions are forced to reduce the basal application of natural source of micronutrients. As such elements like calcium, boron, zinc, iron and manganese availability in the soils have become scarce, leading to deficiencies. Further micronutrient is present in water soluble form in soils and thus there is possibility of its leaching down to lower levels below the root zone, especially in the absence of organic matter. The need for use of calcium, zinc, boron and other micronutrients in these soils for maximizing crop yield is therefore, obvious.

Symptoms of micronutrient deficiencies clearly appear on cultivated plants in Karnataka soil because most of these soils are poor in secondary nutrients especially calcium and with low content of organic matter, all these factors lead to a shortage of readiness of micronutrients. Despite the presence in the soil quantities outweigh the need for the plant (Saleh, 2010), The most vegetable crops grown in these conditions suffer from micronutrient deficiencies and there are a clear response to spray nutrients (Al -Mohammadi, 2005). Kohraee et al., (2011) explained that calcium is essential material for growth and used in small quantities compared to the major nutrients $\mathrm{N}, \mathrm{P}, \mathrm{K}$ and they play an important role in cells division and development, metabolism, respiration increased maturity speed. Alloway (2004) pointed that the use of fertilizers containing calcium element lead to increasing the quantity and improving the quality of tomato when calcium activates enzymes and the representation of carbohydrates and proteins manufacturing. Keeping the above points in view, the field trail was conducted to study the response of tomato to foliar application of calcium metalosate on growth, yield and quality parameters.

\section{Materials and Methods}

The trail was carried out at the farm unit, College of Agriculture, Hassan, which comes under southern Transition Zone (Zone -7) of Karnataka during 2015 on red sandy loam soil with neutral $\mathrm{pH}$ (7.1), low soil organic carbon $(0.51 \%)$, medium available $\mathrm{N}\left(345.3 \mathrm{~kg} \mathrm{ha}^{-1}\right)$, high available $\mathrm{P}_{2} \mathrm{O}_{5}\left(54.8 \mathrm{~kg} \mathrm{ha}^{-1}\right)$, medium available $\mathrm{K}_{2} \mathrm{O}\left(230.0 \mathrm{~kg} \mathrm{ha}^{-1}\right)$ and low in available calcium (1.25 meq/ $100 \mathrm{~g})$. This is situated at latitude of $12^{\circ} 13^{\prime} \mathrm{N}$ and $13^{\circ} 33^{\prime} \mathrm{N}$ latitude and $75^{\circ} 33^{\prime}$ ' and $76^{\circ} 38^{\prime} \mathrm{E}$ longitude at an altitude of $827 \mathrm{~m}$ above mean sea level (MSL). Normal climatic conditions were prevailing during experimental period. The total rainfall received was $384 \mathrm{~mm}$ during the crop season. The average maximum temperature of $33{ }^{0} \mathrm{C}$ in the month of May 2015 and the average minimum of $13{ }^{0} \mathrm{C}$ during the month of December 2015 was recorded. The mean monthly relative humidity ranged from $83 \%$ in May - June to $86 \%$ in July - August. Overall weather condition prevailed during crop growing period was very good and thus, helped to get good crop stand and optimum yield.

The experiment consisted of 7 treatments viz., $\mathrm{T}_{1}$ : Control, $\mathrm{T}_{2}$ : Calcium metalosate at $1 \mathrm{ml} / 1$, $\mathrm{T}_{3}$ : Calcium metalosate at $2 \mathrm{ml} / 1, \mathrm{~T}_{4}$ : Calcium metalosate at $3 \mathrm{ml} / 1, \mathrm{~T}_{5}$ : Calcium metalosate at 4ml/1, T : Micnef @ 5g/l and $\mathrm{T}_{7}$ : Samras @ $2 \mathrm{ml} / \mathrm{l}$. The experiment was laid out in randomized complete block design and replicated thrice. A tomato var. Alankar hybrid was used for experimentation. The land was ploughed twice by tractor drawn mould board plough and cultivator after harvest of previous crop and on receipt of shower on June $2^{\text {nd }} 2015$. After harrowing, the land was 
smoothened with wooden plank. All the plots were dug manually and clods were crushed and leveled. The plots were demarcated as per layout and bunds were raised around each plot. The recommended dose of $\mathrm{N}: \mathrm{P}_{2} \mathrm{O}_{5}: \mathrm{K}_{2} \mathrm{O}$, 250:250:250 kg/ha was applied as per the recommendation and $25 \mathrm{t} \mathrm{ha}^{-1}$ of FYM was applied and incorporated three weeks in advance. Hand weeding fallowed by harrowing at 25 days after planting and earthing up was done using plough @ 30 days after planting.

Micronutrient mixtures like Calcium metalosate, Micnef and Samras were sprayed at given concentration at 30 DAT (July 4th 2015), 45 DAT ((July 19th 2015), and 60 DAT (August 04th 2015). The crop was given one spray of Dithane M-45 @3g/l and Imidacloprid @2ml/1@30 DAT. Another spray of Moximate @ 3g/l and Monocrotophoswas given@2ml/1@45DAT. Another spray of $\lambda$-Cyhalothrin and Matco + @ 60DAT. Periodic harvesting of tomatoes in four pickings was done when the fruits attained maximum size and just turning to reddish colour. By adding the yield of each picking total yield was computed. The data obtained from various studies were statistically analyzed following the procedure as described by Gomez and Gomez (1984).

\section{Results and Discussion}

\section{Growth parameters}

Application of calcium metalosateat different growth stages had significant influence on growth parameters over control. At harvest, among all the treatments, calcium metalosate @ $4 \mathrm{ml} / \mathrm{l}\left(\mathrm{T}_{5}\right)$ recorded significantly higher plant height $(126.087 \mathrm{~cm})$, more number of leaves (52.80), number of branches per plant (16.10) and total dry matter production $\left(152.13 \mathrm{~g} \mathrm{plant}^{-1}\right)$ as compared to control $\left(107.16 \mathrm{~cm}, 49.73,13.90\right.$ and $141.68 \mathrm{~g} \mathrm{plant}^{-1}$, respectively). However, it was on par with calcium metalosate @ $3 \mathrm{ml} / \mathrm{l}(124.95 \mathrm{~cm}$, 52.43, 15.97 and $152.08 \mathrm{~g}$ plant $^{-1}$, respectively) (Table 1). This could be due to the compound effects of many factors, namely additional nutrient, improved soil physical properties, water regimes, better water extraction, aeration and resource use rather than conventional tillage (Unger and Jones, 1998). This might be due to optimum availability of nutrients through foliar application of mineral mixture at appropriate growth stage which enhanced rate of photosynthesis and consequently led to better vegetative growth. Increase in dry matter production indicating that photosynthates were effectively translocated from haulms to fruits. Increased dry matter in fruits may be attributed to increased leaf area and consequent increase in production of photosynthates and better root growth and spread due to the application of mineral mixture which helped in increasing absorption of nutrients and also translocation of photosynthates to fruits. Similar results were concurred with Krishnamurthy et al., (2002) and Ali et al., (2013).

\section{Yield and yield attributing parameters}

Crop growth and productivity are influenced by both external and internal factors. Nutrient management is one such important factor. The yield parameters of tomato varied significantly due to application of various levels of calcium metalosate. The higher number of fruits per plant, average weight of ten fruits, and total yield $\left(32.15,998.00 \mathrm{~g}\right.$ and $25.22 \mathrm{t} \mathrm{ha}^{-1}$, respectively) were recorded with foliar application of calcium metalosate @ $4 \mathrm{ml} / \mathrm{l}$ $\left(\mathrm{T}_{5}\right)$ which was on par with calcium metalosate@ $3 \mathrm{ml} / \mathrm{l}\left(\mathrm{T}_{4}, 31.87,997.33 \mathrm{~g}\right.$ and $24.76 \mathrm{t} \mathrm{ha}^{-1}$, respectively) and these parameters were lower with control $\left(\mathrm{T}_{1}, 25.83\right.$, $843.33 \mathrm{~g}$ and $18.84 \mathrm{t} \mathrm{ha}^{-1}$ ) respectively (Table 2). 
Table.1 Growth attributes of tomato at harvest as influenced by application of various levels of calcium metalosate

\begin{tabular}{|c|c|c|c|c|}
\hline Treatments & $\begin{array}{l}\text { Plant } \\
\text { height } \\
\text { (cm) }\end{array}$ & $\begin{array}{l}\text { Number } \\
\text { of leaves }\end{array}$ & $\begin{array}{c}\text { Number of } \\
\text { branches }^{-1} \\
\text { plant }^{-1}\end{array}$ & $\begin{array}{c}\text { Total dry } \\
\text { matter } \\
\left(\text { g plant }^{-1}\right)\end{array}$ \\
\hline $\mathrm{T}_{1}:$ Control & 107.16 & 49.73 & 13.90 & 141.68 \\
\hline $\mathrm{T}_{2}$ : Calcium metalosate @ $1 \mathrm{ml} / \mathrm{l}$ & 121.35 & 51.67 & 15.04 & 142.61 \\
\hline $\mathrm{T}_{3}:$ Calcium metalosate @ $2 \mathrm{ml} / \mathrm{l}$ & 124.45 & 52.40 & 15.87 & 147.47 \\
\hline $\mathrm{T}_{4}$ : Calcium metalosate @ $3 \mathrm{ml} / \mathrm{l}$ & 124.95 & 52.43 & 15.97 & 152.08 \\
\hline T5: Calcium metalosate @ $4 \mathrm{ml} / \mathrm{l}$ & 126.08 & 52.80 & 16.10 & 152.13 \\
\hline $\mathrm{T}_{6}:$ Micnef @ 5g/l & 115.19 & 50.27 & 14.08 & 144.66 \\
\hline $\mathrm{T}_{7}:$ Samras@2 ml/l & 113.14 & 50.00 & 14.20 & 141.72 \\
\hline S.Em \pm & 2.00 & 1.62 & 0.41 & 4.36 \\
\hline $\mathrm{CD}(\mathrm{p}=0.05)$ & 6.06 & 4.90 & 1.24 & 11.16 \\
\hline
\end{tabular}

Table.2 Yield and yield parameters of tomato at harvest as influenced by application of various levels of calcium metalosate

\begin{tabular}{|c|c|c|c|c|}
\hline Treatments & $\begin{array}{l}\text { Numbers } \\
\text { of fruit } \\
\text { plant }^{-1}\end{array}$ & $\begin{array}{l}\text { Average } \\
\text { weight of } \\
\text { ten fruits } \\
\text { (grams) }\end{array}$ & $\begin{array}{l}\text { Total } \\
\text { yield } \\
\left(\mathbf{t} \text { ha }^{-1}\right)\end{array}$ & $\begin{array}{c}\text { Keeping quality } \\
\text { of fruits } \\
\text { (mean value in days) }\end{array}$ \\
\hline $\mathrm{T}_{1}:$ Control & 25.83 & 843.33 & 18.84 & 18.67 \\
\hline $\mathrm{T}_{2}$ : Calcium metalosate @ $1 \mathrm{ml} / \mathrm{l}$ & 30.90 & 960.00 & 22.67 & 20.33 \\
\hline $\mathrm{T}_{3}$ : Calcium metalosate @ $2 \mathrm{ml} / \mathrm{l}$ & 31.78 & 996.67 & 23.97 & 28.33 \\
\hline $\mathrm{T}_{4}$ : Calcium metalosate @ $3 \mathrm{ml} / \mathrm{l}$ & 31.87 & 997.33 & 24.76 & 33.67 \\
\hline $\mathrm{T}_{5}$ : Calcium metalosate @ $4 \mathrm{ml} / \mathrm{l}$ & 32.15 & 998.00 & 25.22 & 33.66 \\
\hline T6: Micnef @ 5g/l & 30.79 & 993.33 & 21.76 & 28.33 \\
\hline T 7 Samras@ 2 ml/1 & 26.71 & 861.67 & 18.52 & 22.67 \\
\hline S.Em \pm & 1.60 & 47.42 & 0.73 & - \\
\hline $\mathrm{CD}(\mathrm{p}=0.05)$ & 4.84 & 143.85 & 2.22 & - \\
\hline
\end{tabular}

This may be attributed to higher uptake of nutrients as a result of which the foliage cover was more and led to higher dry matter production per plant due to the added nutrients through foliar application of micro nutrients.

And foliar application of micronutrients increases the physiological process and cell division and elongation which indirectly influence tissue formation and consequently vegetative growth of plant. Similar trend was observed by Sharma et al., (2010).

\section{Acknowledgment}

The authors acknowledge the Indofil Industries Limited for providing funds to conduct experiment at best level and Associate Professor, Department of 
Horticulture, Assistant Professors, Department of Agronomy extending the help to conduct the experiment systematically.

\section{References}

AL- Mohammadi, H. Sh. Sharqi. 2005. Effect of Foliar application of $\mathrm{Zn}$ and $\mathrm{Fe}$ on growth and yield of Sorghum bicolori Moench. Msc. Thesis, College of Agric. Univ. of AL- Anbar University. AL. Farhan, H. N. 2001. Potato Physiology, Awan for information Services, Sanaa, Yemen.

Ali, J., Hussein, M. J. and Makki, N.N., 2013, Effect of foliar application on growth and yield of seven cultivars of tomato, Euphrates Journal of Agricultural Sciences, 5(1):1-7.

Alloway, B. J., 2004. Calcium in soil and crop nutrition International Zinc Association (IZA). www.Zincworld. Org.

Gomez, K. A. and A. A. Gomez. 1984, Statistical Procedures for Agricultural Research, An international Rice
Research Institute Book, Wiley- Inter Science Publication, New York, USA, p. 680.

Kohraee, A. Heydari M, Tavassoli A. 2011. The effect of planting date and source of tubers on the quality of potato tubers in autumn and spring. American Journal of Potato Research, 83:195-206.

Krishnamurthy, N., Abdul Khalak, G.M., Sujith, h. K. and Shivaraj, B., 2002, integrated nutrient supply and management for tomato production in alfisols. Potato Global Research and Development, 2: 85-856.

Saleh, Hammed M., 2010. Effect of foliar application of some micronutrient on grain yield of wheat (Triticum aestium) and some of its components. Journal of Tikrit University of Agricultural Sciences, 10(2): 129- 137.

Sharma, R. C., Trehan, S. P. and Roy, S. K., 2010. Tomato variety differences in nutrient deficiency symptoms and responses to NPK. Better Crops International, 15 (1): 18-21.

\section{How to cite this article:}

Jayaramaiah, R., A. Nataraja, B.T. Naveen Kumar and Pramod, G. 2018. Effect of Calcium Metalosate on Growth and Yield of Tomato (Lycopersicon esculentum Mill.). Int.J.Curr.Microbiol.App.Sci. 7(10): 1371-1375. doi: https://doi.org/10.20546/ijcmas.2018.710.152 